不足ぎみである，再現性のある結果を得るためには， 一定の時間を定めて練和する必要がある。

3. 第三の因子は気温で，特に硬化特性に顕著な影 響を及ぼす。これは設满などの問題もあって制御しに くい因子である。したがって各埋没材に対する特性值 の温度依存度をあらかじめ把握して掞く必要がある.

4. そのた, 水温, 水温と混水此との交互作用执よ び混水比と練和時間との交互作用の影響が若干認めら
れた.

5. 諸因子敏感性といら点では使用した埋没材に大 差はない，一般に敏感な材料はど多くの因子を制御し なければならないが，逆に制御しさえすれば再現性の 高い結果が得られる。

おうりに，材料を提供していただいた而至化学工業 株式会社に厚くお礼申し上げます。

\title{
45. 歯科用レジンのガラス転移点
}

Glass Temperature of Dental Resin

九州電科大学歯科理工学教室 (主任 : 林 一郎教授)

$$
\text { 井上勝一郎・林一郎 }
$$

\section{1. ま えがき}

西科ではポリメタクリル酸メチル(パール状ポリマ 一）にメタクリル酸メチル（モノマー）を加え, ポリ マーの周边を溶解膨潤させることにより, ポリマーを 溶着させた餅状レシンンの段階で加圧成形し，モノマー 自体を重合すると云う特殊な成形法（粉液法）を採用 している.この方法によって得られる重合体の顕微鏡 的に見た構造は，ポリマーだけを加熱加圧して互に融 着した試料あるいは重合法だけを異にする有機ガラス 板を加王成形した試料と比べ，かなり異った顕微鏡像 を呈する. 加蓺融着した試料や有機ガラスによる試料 では比較的に均一な構造をしているのに対し粉液法に よる試料では，パール状ポリマーが互につなぎ合わさ れた形で硬化した不均一な構造を呈している。この不 均一な構造は，重合体の物性にかなりの影響を和よぼ すむのと考え, ディラトメーター1（熱膨張計）を 用いてガラス転移温度（Tg）を測定し，均一と見な し得るポリマーだけを加熱加区し融着した試料扣よび 有機ガラスを加珐成形した試料の $\mathrm{Tg}$ と比較した。 たビスコエラストメーター2）用いて測定した損失弾 性率（分子の運動により失なわれる ェネルギ一の尺 度） 3）の急激に 増大しはじめる温度と $\mathrm{Tg}$ との比較 を試みた，その結果，粉液法による試料の方が加熱瀜 着した試料および有機ガラスよりも $\mathrm{Tg}$ が高くなるこ とを見出した。

\section{2. 実 験 方 法}

2. 1. 試料：試料には粘度平均分子量 $4.3 \times 10^{5}$,
平均粒度68～69ミクロンの純粋なポリメタクリル酸メ チル (パール状) 扎よびメタクリル酸メチルを用い, モノマー重量の $0.5 \%$ 過酸化ベンゾィルを加えて乾 熱重合したものを使用した。重合時間は室温から30分 で $100^{\circ} \mathrm{C}$ と， $100^{\circ} \mathrm{C}$ 時間保ったのち加圧したま ま空気中で徐冷した。試料はポリマーだけを加熱加压 し融着したものと，混液比を0.5および2.0にして重合 したもののろ種を作製した。また市肘の歯科床用レジ ンと比較するためにColmos Dental Productの Delsin （3号）を用い上述と同じ条件下で重合して試料とし た.

2. 2. ガラス転移温度 $(\mathrm{Tg})$ の測定 :

Tg の測定には，当教室で作製した水銀式のディラ トメーターを使用した。オイルバスを用い， $0.5^{\circ} \mathrm{C} /$ $\min$ で温度上昇させながら水銀と試料の膨張量を読取 顕微鏡で測定した。 ポリメタクリル酸メチルのような amorphousな高分子では結晶性高分子に見られるよう な、はっきりしたガラス転移温度を示さないので，低 温部 ( Tg 以下) に护ける熱膨張曲線の接線と，高温 部（Tgより充分に高いと思われる温度）での膨張曲 線に打ける接線との交点を $\mathrm{Tg}$ と定めた。

2. 3. 粘度平均分子量の決定 :

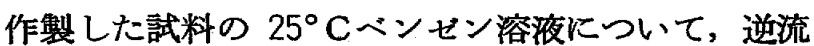
型粘度計を用い 4 〜 点の相対粘度を求め, これより 極限粘度を算出し粘度平均分子量4)を求めた。

\section{3. 実 験 桔 果}

ビスコェラストメーターを用いて測定した損失弾性 
率が急激に増大しはじめる温度, ならびにディラトメ 一ターから得られる熱膨張曲線に打ける接線の交点 ( $\mathrm{Tg})$ と混液比（L/P） の関係を Fig. 1 に図示した.

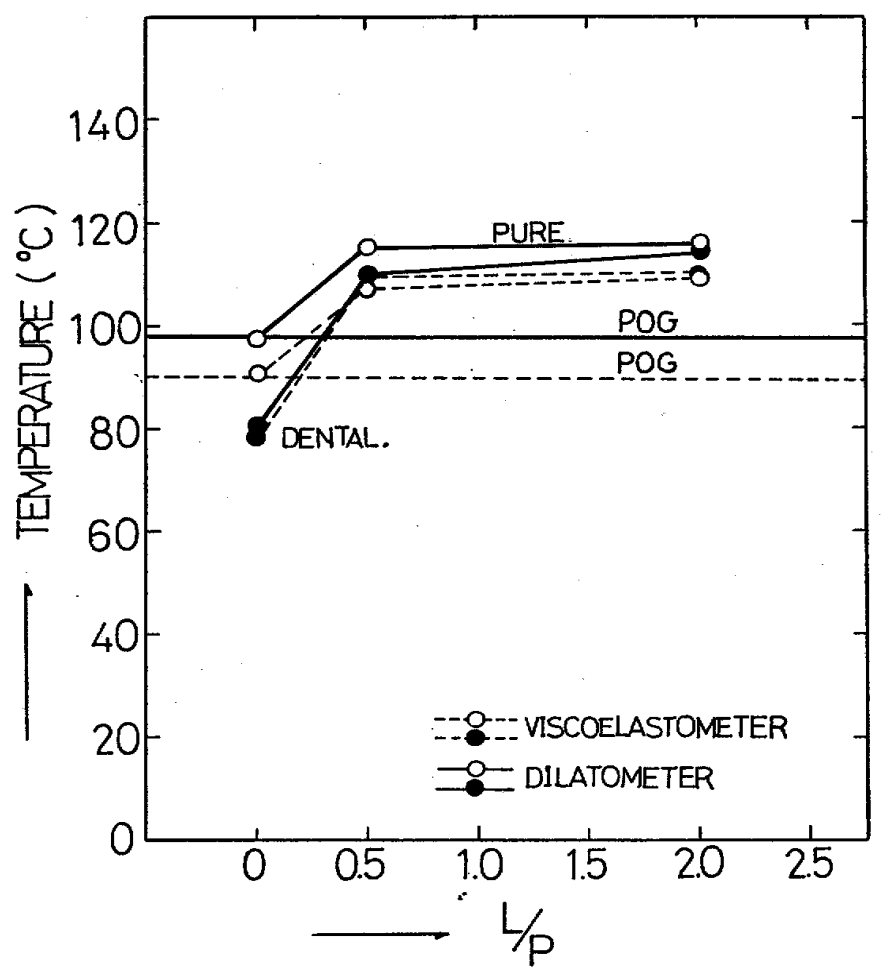

Fig 1. Glass temperature vs. liquid-powder ratio (L/P) for pure polymethyl methacrylate, dental resin and organic glass.

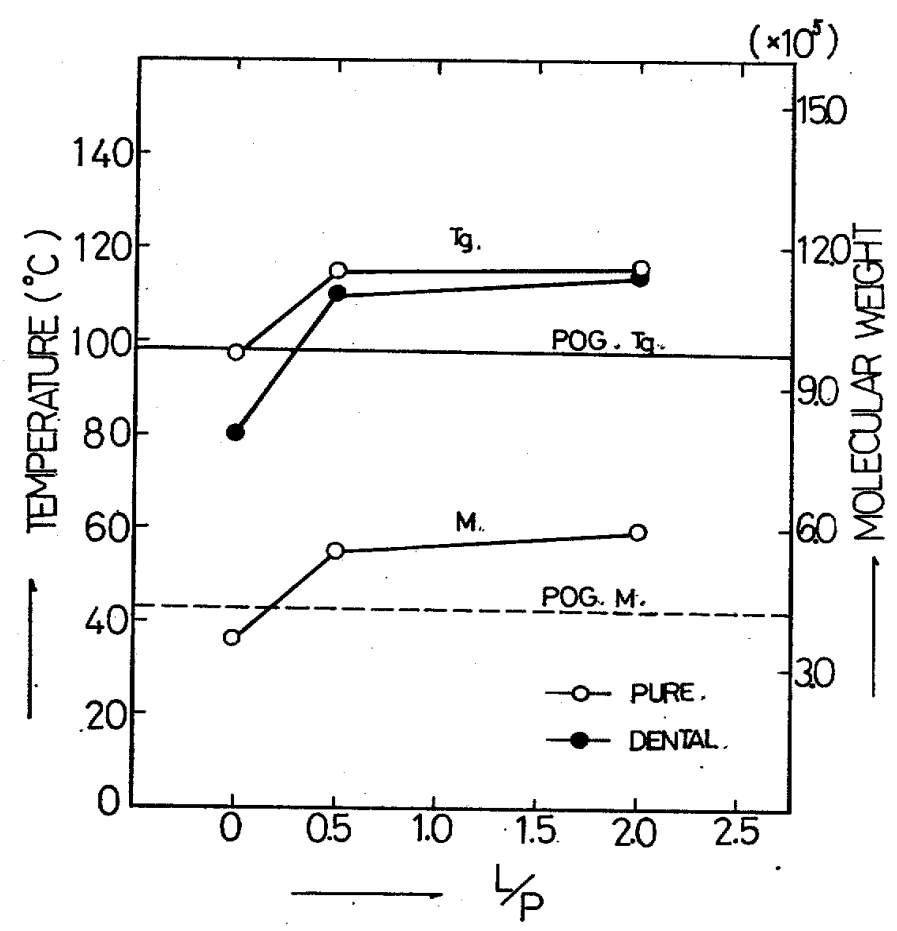

Fig 2. Glass temperature $\operatorname{and}_{\mu}^{*}$ molecular weight vs. liquid - powder ratio $(L / P)$ for pure polymethyl methacrylate.
これによると純粋なポリメタクリル酸メチルおよび 市販の雪科用レジンいずれの場合も粉液成形をほどこ した試料の方がポリマーだけを加熱加王し融着した試 料よりる $\mathrm{Tg}$ が高くなる傾向を示した。

Fig. 2には,ディラトメーターによって測定したTg および分子量とL/Pとの関係を図示した。

純粋なポリメタクリル酸メチルパールの分子量は

$4.3 \times 10^{5}$ 程度であったが，友科的に粉液法で作製し た試料てい，いずれもこの值より増加し，L/P0.5の 試料で $5.5 \times 10^{5} ， 2.0$ 試料では $6.0 \times 10^{9}$ となった。 これに対し加熱融着した試料ではパールのもつ分子量 よりも低い3.6×105を示した。

\section{4. 若察}

歯科的粉液法で作製した試料は，単にポリマーだけ を加熱加王して融着させた試料と比べ，より高いがラ ス転移温度を示し, 分子量においてもパール状ポリマ 一の分子量 $4.3 \times 10^{5}$ よりもさらに大きくなっている. このことは，粉液法で作製した試料では加熱融着した 試料の転移温度付近に沶いて，分子鎖セグメントのミ クロブラウン運動がおこり得ず，これをおこさせるに はさらに高温にまで加熱する必要があることを示して いる. 従って加熱融着した試料の $\mathrm{Tg}$ 付近では, 粉液 法で作製した試料の分子がまだ完全に凍結状熊からと さはなされていないものと思われる。

このことはFig. 1 からも推測できる. 損失弾性率 が急激に増加しはじめる温度, 換言すれば応力緩和現 象が著しくなりはじめる温度が，ポリマーだけを加熱 融着した試料よりも約 $15^{\circ} \mathrm{C}$ 高い $115^{\circ} \mathrm{C}$ 付近に移行す ることから，粉液法による試料の分子鎖セグメントは 加熱融着試料に比べてより高温部まで運動しにくいこ とになる。

純粋な試料の示す $\mathrm{Tg}$ と市販歯科用レジンの示す $\mathrm{Tg}$ との比較に拈いては, 純粋なポリマーだけを加熱融着 した試料の方が，歯科用ポりマーだけを加熱加王し融 着させたものよりも約 $20^{\circ} \mathrm{C}$ 高い温度を示す.これは 㫧科用レシンンに顔料が含まれるため，顔料が可塑剂と して作用するものと考えることができよう.しかし粉 液法で作成した雪科用レジンではL/P 0.5のむので

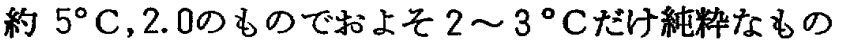
より低い值を示した. 従って粉液成形することによっ て顔料の影響は比較的小さなるのになってしまう。と くにL/P 2.0では Tgに汇とんど差がないと見なし 得るであろら。 
-240- ( 94 ) 54. 歯科用レシンのガラス転移点

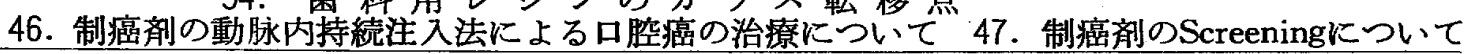

Tg の上からだけではL/Pが 2.0の試料が最も緩和 しにくいといえるが，ポリマーに対するモノマーの量 が多いと重合による収縮などの点で 大きな疑問が残 る.

5. ま と め

以上が本実験に抬ける考察であるが，Tg 以上での 粘弾性挙動，あるいは粒度分布，分子量分布など物性 に影響を与えると思われるデーターをさらに集め検討 したいと考えている.
文 献

1）日本化学会編：実験化学講座 (下)，94, (1956).

2）井上勝一郎, 林 一郎; 齿科用レジンの動的粘 弾性 : 歯科理工誌投稿中.

3 ) A. D. Ferry; Viscoelastic properties of polymer, 31, (1960).

4) 日本化学会編：実験化学講座 (上)，152, (1956) .

\section{6. 制癌斉の動脉内持続注入法による口腔癌の 治療について}

On the Treatment for Oral Cancer by Regional Intra-arterial Inf usion Method of Carcinostatic Agents

\section{7. 制 癌剂の Screening について}

On the Screening of Carcinostatic Agents

九州歯科大学第 2 口腔外科学教室 (主任 : 池尻 茂教授)

池尻茂

従来から，悪性腫汮に対する処置としては，(1)原発 巣根治手術。(2)放射線療法，(3)化学療法，がそれぞれ 単独に，或は 2 者， 3 者の併用療法が採用されてき た. 近年, 特に各種制癌㓮の開発と，その投与法に関 する研究がすすめられているが，いまだに手術，放射 線療法が主役をなし，化学療法は傍役の域をでていな W.

しかし，浸潤，播種，転移の危懼から開放されない 癌に対して，手術，放射線療法の久では，広範囲にわ たる完全な処置は困難である．特に顔面部初発の癌に 対しては，著しい顔面部の醜形をきたす可能性がある ため，化学療法に期待を寄せるところが大きい．

私の教室では, ここ数年来, 口腔癌に対して, 教室 独自の治療方針を採用して扣り，特に治療効果及び副 作用緩和の両面に対する考虑から，感受性試験下にお ける各種制癌剤の動脉内持続注入法を実施しているの で，その概要を映画によって供覧する。

\section{［I ]腫痬の大きさが示指頭大以上の場合}

腫瘍部分の切除を行い, その一部で病理組織診断, 残部て感受性試験を行う．感受性の強い制癌剤が決定 したならばただちに充分量の制癌剤を局所動脉内に 持続的に注入する．必要に応じて全䫫部廓清術を施す
が，この場合，頸部転移巣の有無が指標である。しか し，上顎癌では消極的に，舌・口底・下顎癌では積極 的に頸部廓清術を行ら方針をとっている. 又, 場合に よっては, 術前, 術中の制癌剤動注を行いながら，原 発巣に対する切除根治手術も考慮する. 感受性試験を 行っても，特に感受性の強い制癌剤が見当らない場合 には, 病巣の根治手術を行う. 場合によっては頸部廓 清術, 或は術前照射を行って後, 根治手術を施すこと も考虑する.

\section{〔II 腫痬の大きさが示指頭大以下の場合}

腫瘍全部摘出手術を行い，前者と同㥞に一部で病理 組織診を，残部て制癌㓮の感受性試験を行う。感受性 の強い制癌剤が決定し，再発の恐れがあれば，制癌成 動注を行うのであるが，場合によっては再手術或は放 射線療法を行う．再発の恐れが少い場合は経過を観察 する. 感受性の強い制癌剈が見当らないで，しかも再 発の恐れが濃厚な場合は, 再手術, 放射線療法を考虑 し，更に，適正な制癌剤の動注を行う。再発の恐れが 少い時は経過を観察する.

\section{[III] 感受性試験}

制癌剤を投与してむ薬効が現れず，場合によっては 却って症状の 増悪を示すことが 経験的に知られてい 